Галина П. ТИРТОВА*

Московский государственный университет имени М.В. Ломоносова Филологический факультет
Оригинални научни рад

Примљен: 23. 10. 2016. Прихваћен: 10. 02. 2017.

\title{
О НЕКИМ АСПЕКТИМА АДАПТАЦИЈЕ АНГЛИЦИЗАМА У СРПСКОМ ЈЕЗИКУ
}

\begin{abstract}
У раду се разматрају питања асимилације позајмљеница из енглеског језика на фонетском, графијском и граматичком нивоу. Посебна пажња је посвећена принципима преноса на ћирилицу. Ради се и о релативно новим појавама као што су синкретизам врста речи и непроменљивост атрибута. Закључује се да језик прималац тежи да потчини позајмљенице својем морфолошком и творбеном систему.

Кључне речи: асимилација, непроменљиви атрибут, синкретизам, творбено гнездо, транскрипција, транслитерација, трансплантација
\end{abstract}

Речи страног порекла (турцизми, германизми, романизми, мађаризми итд.) заузимају значајно место у речничком фонду српског језика. На савременој етапи, најинтензивније у језик улазе англицизми. „Енглеска болест” (према духовитим речима једног слависте) која је последњих деценија захватила многе европске језике има више узрока. Главни од њих је неопходност да се именује нова појава за коју језик-прималац нема своју реч. Пре свега те позајмљенице се односе на економију, банкарство, рачунаре, електронику, рекламу, масовну културу и др.: гламур, дискета, картинг, ласер, маркер, маркетинг, пејцер, панк, рели, фајл, хепенинг, хипхоп итд.

Знатан број англицизама прихваћен је као резултат тежње језика ка семантичкој и структурној компактности. У том случају, позајмљеница која се састоји од једне речи (лексеме) типа фрилансер, мастерклас, конкурише српском описном изразу. У конкуренцији су опен и отворено првенство, цакузи и хидромасажна када, ноухау и високостручно знање и умење које је потребно да се нешто направи. Наравно у овој конкуренцији побеђује једночлана јединица.

"tyrtova58@mail.ru 
Асимилација англицизама у нови језички систем одвија се у складу са законима српског језика и то на неколико нивоа: фонетском, графичком, граматичком, семантичком и стилистичком. Већ на прва два нивоа почиње процес адаптације и позајмљеница губи првобитни облик. Пре свега се врши преношење са латинице на ћирилицу или на српску варијанту латинице.

При преносу на ћирилицу српски језик користи два „техничка” принципа - транскрипцију и транслитерацију. Под првом подразумевамо преношење звучања оригинала, а под другом - препис „слово по слово” позајмљене речи. Транслитерацију видимо како у позајмљеницама које су давно ушле у језик (типа камn), тако и у онима новијег датума билборд, перформанс, опен (у синтагми Аустралијан опен). Међутим, има примера који показују да се преношење појединих гласова током времена мења у корист транскрипције. Тако се, енглеско „а" ( изговара се у изворном језику као отворено широко „е”) више не преноси као „,а" (примери типа менаимент, дигиталан, камn), него се сада преноси као „е”: cash - кеш, rapper - penep, happening - хепенинг. Ако је у случају са „a” победила транскрипција, у преношењу енглеског слова „w” према давнашњој традицији наставља да се користи транслитерација, односно англицизми са почетним „W” као и раније у српском пишу се са „в”: воки-токи (walkie-talkie), вокмен (walkman), Волстрит (Wallstreet). У руском језику у последњој речи запажа се транскрипционо преношење „w” као „у сматра да је у руском језику транскрипција без обзира на неке недоследности скоро потиснула транслитерацију. Сада се још не може донети овакав закључак и о српском језику, али је употреба транскрипције у порасту.

Помоћу транскрипције се преносе речи: гејт, римејк, ноухау, копирајт, цез, репер, саундтрек итд. У називима филмова, новина, часописа, музичких група као што су „Блек сабат”, „Алман брадерс бенд”, „Бич бојси”, „Аватар”, „Бибиси сингерс”, „Биг тајм” срећу се транскрибоване речи, односно видимо „класично” пребацивање енглеске латинице на српску ћирилицу. Појава речи као што су: плејстејшн, пабликрилејшн, нон-фикшн, еркондишн, само потврђује да се транскрипција користи све чешће: комбинација ШН одражава тачан изговор енглеских суфикса -tion, -sion који се никада раније нису преносили на такав начин: енг. promotion - срп. промоција, енг. installation - срп. инсталација, енг. session - срп.сесија

Интересантни су случајеви типа рисивер (енг. receiver) у којима се запажа спој транскрипције (у прва два слога) и транслитерације (у последњем слогу).

У савременом српском језику се често могу видети називи филмова, песама, музичких композиција и сл. који се не преводе, не транскрибују и не транслитеришу на ћирилицу, већ се пишу као у енглеском језику: „Thriller” (песма Мајкла Џексона), „In the Wee Small Hours” (песма Френка Синатре), „Rubber Soul” (песма групе „Битлси”), „Nevermind” (група „Нирвана”), „Saving Christmas” (назив филма), „Dragonfly Inn” (назив фирме). То су примери тзв. нулте адаптације или трансплантације. Позајмљенице употребљене у онаквом облику какав имају у језику-даваоцу, Иван Клајн је назвао „интегралним позајмљеницама". 
Занимљиви су случајеви када се буквално на истој новинској страници срећу два принципа преношења једне исте речи. Назив филма је у једном случају написан Paddington (трансплантација), а у другом је иста та реч транскрибована Меда Педингтон, и то тако да је транскрипција праћена додавањем речи које нема у изворном називу (трансформација додавања). То говори о томе колико је савремени језик слободан у избору начина преношења англицизама, нарочито ако се ради о ,jеднодневним речима" које се не задржавају дуго у језику.

Реч Педингтон је и пример промена до којих долази на другој етапи асимилације англицизама. Мења се ортографија ${ }_{2}$ наиме губе се удвојени сугласници који нису карактеристични за српски језик: дискета (енг. diskette), репер (енг. rapper), самит (енг. summit), хепи (енг.hарру), Конектикат (енг. Connecticut). На другој етапи обликовање неких енглеских позајмљеница прати регресивно једначење по звучности. Управо су тако у потпуном складу са нормама српског језика обликовани давно позајмљени англицизми као што су фудбал, бејзбол и сл. Ипак се међу англицизмима новијег датума запажају случајеви у којима се такво једначење не врши: гангстер, регтајм, Редфорд, Гибсон. Пошто такво преношење подрива принцип доследног „фонетизма”, може се претпоставити да ће се временом и те речи писати другачије.

На граматичком нивоу у асимилацији енглеских речи одиграва се неколико процеса. Тако је, на пример, могућа промена броја именица. Речи sociolinguistics, psycholinguistics, pragmatics које се у енглеском језику употребљавају у облику множине асимиловале су се у систем српског језика у облику једнине: сочиолингвистика, психолингвистика, прагматика. Интересантни су случајеви типа „Трансформерси”, „Бич бојси”, „Битлси”, када је у језику-даваоцу употребљена множина, а у језику-примаоцу овом облику је још додата флексија -и, карактеристична за српски плурал и на тај начин као да добијамо ,дуплу множину”.

Пошто је „енглеска болест” захватила све словенске језике, занимљиво је размотрити има ли разлика у томе како се, на пример, врши граматичка адаптација англицизама у три словенска језика - српском, чешком и руском. Што се тиче именица мушког рода са основом на сугласник и нултим завршетком у сва три језика, оне су интегрисане у систем деклинације: рус.: купил в секондхенде, был на кастинге, без бекграунда; чеш.: make-ирет, sekondhandu, comebaku. У српском сличне позајмљенице добијају све карактеристике деклинације таквих именица. Код њих запажамо сибиларизацију, односно смењивање задњонепчаних к, г, х њиховим зубним алтернантима ц, 3, с: кастинг - кастинзи, лизинг - лизинзи и слично, а ако су у питању једносложне именице, онда оне у множини проширују основу:

...у продаји још мали број карата за места у „скај-боксовима”

Велики број фанова Ди-цејеви True Thin и Subvice

Ниво интеграције у сва три језика је скоро исти, мада и у чешком, и у руском ипак има непроменљивих именица (рус. смc, чеш. open, cash), док у српском падежне наставке добијају све речи: počeo sam razgovarati sms-om; 
večito pišem o dobrom site-u. Што се тиче англицизама које се завршавају на самогласник, у српском и руском језику они се усвајају потпуно у складу са постојећим правилима. Пошто се у руском језику традиционално стране именице на самогласник не мењају (пианино, кафе, бистро), немају деклинацију ни нове (диско, мачо, ноухау). У српском језику традиционално се све ове позајмљенице мењају по падежима:

\footnotetext{
...креативни директор „Барберија” ...радови Жана Пола Готијеа

...кухиња Гордона Рамзија , диско - диска, ретро - ретра, мачо - мачоа, ноухау - ноухауа.
}

Мало је другачија ситуација у чешком језику. У граматикама се констатује да се упркос законима морфолошког система фонд именица и придева који се не мењају попуњава између осталог на рачун енглеских речи на самогласник (body, ecu, graffiti, lobby itd). Сви ови примери показују да се адаптација у три језика врши отприлике једнако, али српски језик мало активније него остала два подређује позајмљенице свом језичком систему.

На граматичком нивоу адаптације одвија се и процес лексикализације - претварање енглеске фразе у једну реч у српском језику. На пример, реч рентакар добијена је слагањем енглеског глагола, члана и именице: rent-acar. Као резултат лексикализације повећава се број сложеница у српском језику: фастфуд, мастерклас, прајмтајм. У појединим случајевима могуће је писање са цртицом: дрим-тим, слајд-иоу, диск-иокеј.

Учешће позајмљене лексеме у процесу извођења речи у језику-реципијенту - показатељ је високог степена асимилације англицизама. Од страних имена лако се образују присвојни придеви (Галијанова ревија, Дизнијев филм), док многи други англицизми постају творбена основа за читаво творбено гнездо: кул - кулирати, кулирање, кулер, кулерка; реп - реповати, реповање, репер, реперка, реперски; менаиер -менацерка, менацерски, менацерство. Нарочито су значајни примери срастања енглеске основе и српских суфикса. Доста примера се може наћи како међу именицама (хевиметал - хевиметалаи, рекет - рекеташ, скутер - скутераш), тако и међу глаголима: не блогах

Компаније су спонзорисале наступ извођача. Десило се много тога у времену у којем

Нарочито је интересантан последњи пример који смо нашли у CMC-поруци. Од англицизма је направљен облик имперфекта, али није сасвим јасна мотивна основа (да ли постоји глагол блогати?).

За неке енглеске речи које су ушле у српски језик карактеристичан је синкретизам врста речи. То значи да једна иста реч, у зависности од реда речи у реченици, може да врши функцију и именице и придева. Ако се англицизам налази испред именице, онда он наступа у улози придева, а у осталим случајевима - у улози именице: седети у кокпиту (именица) - кокпит спреј (придев), два најновија ласера (именица) - ласер коагулација (придев), панк као музички жанр (именица) - панк епоха (придев). Исте такве карактеристике имају речи: компјутер, консалтинг, ретро, мачо и сл. 
Захваљујући моделима такве врсте, последњих деценија се повећава број синтагми са непроменљивим атрибутима у препозицији у односу на именицу: филтер кесица, лукс сапун, камилица чај, фитнес иентар, релакс зона, цез мајстор, голф терени.

Последње наведене конструкције изворно нису биле карактеристичне за српски језик. Њихово појављивање, постојање речи које се изговарају према правилима различитим од правила српског језика (гангстер и сл.), као и неке друге појаве, говоре о одређеној интерференцији. Утицај енглеског језика је толико велик да се понекад може говорити да је за млађе генерације карактеристичан својеврсни српско-енглески билингвизам. На пример, у њиховим CMC-порукама (писаним латиницом) срећу се и овакве фразе:

...i kasnije svratismo do krke and pravac home ...odmah ide deo gde upisujem birthday ...ostavio sam lucky.

Значи ли то да се поставља питање о језичкој опасности? Ипак би одговор био негативан. Језик-прималац тежи да потчини позајмљенице свом језичком систему и тако долази до њихове интензивне адаптације. Морфолошка и творбена стандардизација српског језика су његов заштитни фактор. Шта се може рећи о будућој судбини англицизама у српском језику? Бохемисти, говорећи о проблему англо-американизама у чешком језику, претпостављају да ће модерне речи разних врста током времена отићи у други план или сасвим нестати, да ће изаћи из употребе. Остаће само они термини за којима постоји „друштвена” потреба. Вероватно се исти закључак може применити и на српски језик. У њему ће остати оне речи које су попуниле „терминолошки вакуум" у разним областима науке, привреде, економије, информације. То су речи типа брокер, гаиет, дилер, естаблишмент, компјутер, менаиер, ноутбук, провајдер, чартер, хакер и многе друге. У језику ће остати и оне речи које су се појавиле да би разграничиле појмове или њихове специјализације. На пример, именица постер означава нови вид плаката, наиме „фотографију популарне личности или музичке групе, одштампану на великом листу папира", а таблоид је врста новина обавезно са великим бројем фотографија и сензационалним или псеудосензационалним материјалом. Сада ове речи егзистирају упоредо. Као резултат диференцијације значења у српском језику су се укорениле речи као што су: имиц, килер, саспенс, ток-шоу и др.

Конкуренција између позајмљеница и својих речи - појава је која постоји у сваком развијеном језику. 


\section{ЛИТЕРАТУРА}

Васиљева/Широкова 2003: В.Ф. Васильева, А.Г. Широкова, „Чешский язык в новом тысячелетии (общая характеристика языковой ситуации и динамических инноваций)", Славянский вестник, вып. 1, Москва, 46-69.

Володарскаја 2002: Э.Ф. Володарская, „Заимствование как отражение русско-английских контактов”, Вопросы языкознания, № 4, Москва, 96-118.

Клајн 1996: И. Клајн, „Два правописна проблема у вези са страним речима”, у: О лексичким позајмљеницама, Суботица-Београд, 121-127.

Хлебец 2003: Б. Хлебец, Преводилачке технике и поступци, Београд: EBG д.о.о.

Васић и др. 2001: V. Vasić i dr., Rečnik novijih anglicizama, Novi Sad: Zmaj.

Галина Тиртова

О НЕКОТОРЫХ АСПЕКТАХ АССИМИЛЯЦИИ АНГЛИЦИЗМОВ
В СЕРБСКОМ ЯЗЫКЕ

Резюме

Ассимиляция англицизмов (их появление связано с такими причинами, как необходимость называть новые предметы и явления, заменить многочленные дефиниции одним словом и др.) происходит на пяти уровнях. На первых двух уровнях, фонетическом и графическом, происходит переход с латиницы на кириллицу, причём используются два «технических способа», транскрипция и транслитерация. В настоящее время транскрипция используется чаще, нежели раньше. Используется и такой способ оформления англицизмов, как трансплантация. На грамматическом уровне адаптации интересно изменение формы числа, а также включение в падежную систему языка-реципиента. Последний аспект рассматривается в сравнительном плане на материале не только сербского, но и чешского, и русского языков.

В статье приводятся примеры формирования словообразовательных гнёзд с заимствованием в качестве основы. Затрагиваются также вопросы частеречного синкретизма и возникновения словосочетаний с неизменяемым атрибутом.

Ключевые слова: ассимиляция, несклоняемое определение, синкретизм, словообразовательное гнездо, транскрипция, транслитерация, трансплантация. 